\title{
The Implementation of Antenatal Care with Telehealth Towards Pregnant Women's Mental Health
}

\author{
Angelia Friska Tendean ${ }^{1,2}$, Arlina Dewi ${ }^{3}$, Anggit Wirasto ${ }^{4}$ \\ ${ }^{1}$ Correspondence Author: angelia.tendean@unklab.ac.id \\ ${ }^{1}$ Faculty of Nursing, Universitas Klabat, Indonesia \\ ${ }^{2}$ Master of Nursing student, Universitas Muhammadiyah of Yogyakarta, Yogyakarta, Indonesia. \\ ${ }^{3}$ Master of Hospital Administration, Universitas Muhammadiyah of Yogyakarta, Yogyakarta, Indonesia \\ ${ }^{4}$ Department of Information Technology Science and Technology Faculty Harapan Bangsa University,
} Purwokerto, Indonesia

\begin{tabular}{|c|c|}
\hline I N D E X I N G & A B S T R AC T \\
\hline $\begin{array}{l}\text { Keywords: } \\
\text { Antenatal Care; } \\
\text { Mental Health; } \\
\text { Pregnant Women; } \\
\text { Telehealth; }\end{array}$ & $\begin{array}{l}\text { Mental health problems among pregnant women must be prevented or managed to } \\
\text { prevent possible complications that can impact to both mother and fetus, which can be } \\
\text { carried out together with Antenatal Care (ANC). Telehealth is a technology-based } \\
\text { approach to improving maternal health care. This study aimed to discuss evidence } \\
\text { related the implementation of ANC with telehealth towards pregnant women's mental } \\
\text { health. This study design was literature review conducted by searching databases of } \\
\text { PubMed, Proquest, Cochrane Review, and EBSCOhost databases from } 2000-2020 \text {. The } \\
\text { result showed the mode of telehealth had been used varies in nine articles, with the } \\
\text { most participants were using handphones } 56 \% \text { and computers } 11 \% \text {, and both } \\
\text { combination } 22 \% \text {, while application-based } 45 \% \text {, websites } 22 \% \text {, software } 11 \% \text {, internet } \\
11 \% \text {, and SMS } 11 \% \text {. Implementing telehealth with ANC made it possible to effectively } \\
\text { detect early mental health and manage the problem. The result has also shown that } \\
\text { telehealth has achieved a good satisfaction level. The common factors that influence } \\
\text { telehealth's efficacy include income, education, the age of pregnant women, and } \\
\text { gestational age. It can be concluded that telehealth with ANC can effectively improve } \\
\text { mental health among pregnant women and be recommended for use by health care } \\
\text { providers. }\end{array}$ \\
\hline
\end{tabular}

Kata kunci:

Antenatal Care Kesehatan Mental Ibu Hamil

Telehealth
Masalah kesehatan mental pada ibu hamil harus bisa dicegah maupun diatasi untuk mencegah kemungkinan komplikasi yang bisa terjadi pada ibu maupun janin yang dapat dilaksanakan bersamaan dengan pemeriksaan Antenatal Care (ANC). Telehealth merupakan sebuah teknologi untuk meningkatkan pelayanan kesehatan maternal. Tujuan penelitian ini untuk membahas implementasi dasar ANC bersama telehealth terhadap kesehatan mental ibu hamil. Desain penelitian ini yaitu literature review dimana metode pencarian artikel menggunakan database PubMed, Proquest, Cochrane Review dan EBSCOhost tahun 2000-2020. Hasil Artikel yang direview berjumlah sembilan artikel. Hasil menujukkan mode telehealth yang digunakan bervariasi, paling banyak partisipan menggunakan handphone 56\% dan komputer $n=11 \%$, dan kombinasi $22 \%$, sementara berbasis aplikasi 45\%, website 22\%, software 11\%, internet 11\%, SMS 11\%. Implementasi telehealth bersama ANC efektif dapat mendeteksi awal permasalahan kesehatan mental dan manajemen masalah kesehatan mental, tingkat kepuasaan penggunaan telehealth berada pada kategori baik. Faktor-faktor utama yang dapat mempengaruhi keefektifan penggunaan telehealth antara lain pendapatan, pendidikan, usia ibu hamil dan usia kehamilan. Kesimpulan Telehealth bersama ANC efektif dapat meningkatkan kesehatan mental ibu hamil dan dapat direkomendasikan untuk digunakan pemberi layanan kesehatan. 


\section{INTRODUCTION}

Mental health issues currently attract attention in the worldwide because it can affect everyone, including pregnant women. The prevalence of mental health condition in pregnant women was high. Most of the problems among pregnant women were depression and anxiety, and other problems such as stress adjustment and somatoform (Sheeba et al., 2019; Fawcett et al., 2019; Khatri et al., 2019). World Health Organization (WHO) mentioned that $10 \%$ of pregnant women worldwide experienced mental health problems (WHO, 2019). The previous study also showed that pregnant women experienced depression at $9.3 \%$, anxiety at $16.9 \%$, likewise another study in Ethiopia showed $21.5 \%$ of pregnant women experience depression (Wallwiener et al., 2019; Duko et al., 2019).

The problem of mental health among pregnant women must be detected and must be addressed immediately. If this problem is not resolved, it may affect the fetus, newborn, and pregnant women (Howard and Khalifeh, 2020). In fetuses or newborn, the adverse affected were premature newborn, babies with low birth of weight, low APGAR scores, recurrent respiratory tract infections, impaired fetal neurodevelopment and the other problem were cognitive, behavior, self-regulatory, and children's socio-emotional in the future (Mongan et al., 2019; Korhonen et al., 2019; Lautarescu et al., 2020; Madigan et al., 2018). This is maybe due to changes in the fetal brain structure development, neurodevelopmental disorders, the function of neurocognitive, process of brain, structure, and function of brain connectivity during pregnancy, that is affected by the amygdala and prefrontal cortex, which changes axis of Hypothalamus Pituitary Adrenal (HPA), autonomous nervous system and cortisol regulation (Franke et al., 2020; Van den Bergh et al., 2020; Lewis et al., 2016). Adverse effects that can occur in mothers include increasing postnatal depression or anxiety, miscarriage, cesarean delivery, and preeclampsia (Hartman et al., 2020; Wesselhoeft et al., 2020).

There are certainly many factors which influence the mental condition in pregnant women. Those factors include relationship mother-in-law and pregnant women, artificial insemination, no physical-exercise, low self-efficacy, low social support, poor sleep quality, low income, unmarried, housewives, education level of pregnant women and spouse, experiencing unwanted pregnancies, suffering from chronic diseases before becoming pregnant, having problem-related to pregnancy, having disabled children, smoking during pregnancy, a history of abuse or domestic violence, and miscarriage (Yu et al., 2020; Mossie et al., 2017; Biaggi et al., 2016).

Mental health problem was reasonably big among pregnant women, which indicates the regular screening and management of mental health problem were needed to be a part of routine ANC (Johnson et al., 2018) (Woldetsadik et al., 2019). ANC is a pregnancy examination that includes nutrition for pregnant women, mother and fetus assessment, preventive measures, interventions to treat common physiological symptoms such as nausea, heartburn, constipation (Tunçalp et al., 2017). According to WHO, ANC also improves the lives of pregnant women by providing an effective communication between pregnant women and health workers, as a support system from any aspects (social, cultural, emotional, and psychological), and recommendations for ANC visits to be done at least 8 times during pregnancy (World Health of Organization, 2016). Low ANC visits during pregnancy will adversely affect pregnant women (Chen et al., 2020). Several studies have revealed factors that influenced ANC visits at health facilities, including mother and husband education, pregnancy planning, residence, age, sources of information, knowledge, level of health facility satisfaction, parity, and long distances to health facilities (Abosse et al., 2010; Terefe 
and Gelaw, 2019; Agus and Horiuchi, 2012; (Konlan et al., 2020. Telehealth is one of the strategies used to increase ANC visits' attendance (Watterson et al., 2015) (Benski et al., 2020).

Telehealth is a technology-based health service in communicating to improve patients' health status (Tuckson et al., 2017). Telehealth provides general health services and pregnant women, including ANC. The goal of telehealth for pregnancy is to maintain patient access to perform ANC examinations in health services (Krenitsky et al., 2020). ANC visits were hampered and unfulfilled (Zork et al., 2020). Telehealth health services are easy to reach, more economical, and more affordable (Lanssens et al., 2017). However, some pregnant women still doubt about the quality of health services through telehealth. It is essential to convince these technology services' quality and safety and build mutual trust between pregnant women, health care providers, and related effects of technology (Wu et al., 2020). Previous studies have been investigated regarding telehealth with ANC in health providers, including telehealth's effectiveness towards mental health problems in pregnancy. This study's purpose is to discuss the available literature related implementation of ANC with telehealth on mental health problems in pregnant women.

\section{RESEARCH METHOD}

The method was a literature review. The literature was conducted in December 2020 using PubMed, Proquest, Cochrane Review, and EBSCOhost databases. The keywords were searched using Medical Subject Heading (MeSH) and other free keywords, and the search list can be seen in table 1. The author uses Preferred Reporting Items for Systematic and Meta Analyses (PRISMA) to guide review reports.

Table 1. Keywords Search

\begin{tabular}{ll}
\hline \multicolumn{1}{c}{ Keywords } & \multicolumn{1}{c}{ Synonym } \\
\hline Telehealth & telehealth OR telemonitor OR digital health OR audio-video virtual OR mHealth OR \\
& m-Health OR mobile health OR video conferencing OR mcare OR mobile phone OR \\
& mobile device OR mobile technology OR mobile telehealthcare OR mobile \\
& communication OR communication satellite OR enterprise digital assistants OR cell \\
& phone OR telepractice OR mobile telemedicine OR telecare OR technology OR \\
& teleconference OR telenursing OR teletherapy OR telemental OR cellular phone OR \\
& personal digital assistant OR PDA OR mobile tablet computers OR smart-phone OR \\
& smartphone OR apps OR mobile applications OR text message OR short message OR \\
& short message service OR SMS OR multimedia message OR MMS OR texting OR \\
& multimedia technology OR multi-media message \\
\hline ANC & Antenatal care OR Prenatal care OR Perinatal care OR Pregnant Care \\
\hline Pregnant & Pregnant OR pregnancy OR pregnant women OR prenatal OR antenatal OR perinatal \\
& OR gestational \\
\hline Mental Health & Depression OR depressed OR stress OR anxiety OR mental OR mental health OR mental \\
& health illness OR mental health disorder \\
\hline
\end{tabular}

The inclusion criteria were focused on implementing telehealth in pregnant women who performed ANC related to mental health, including depression, stress, anxiety. The population was pregnant women, study designs were experimental, cohort, case control, cross sectional study and qualitative studies, articles have abstract, peer-reviewed, full text, English language, and published in 2000-2020. The exclusion criteria or articles excluded were articles that were not related to telehealth interventions on mental health, non-pregnant women population, not conducted together with ANC, preliminary research, protocol research, review-type articles, comments, and letters to the editor. All relevant articles were screened base on inclusion and exclusion criteria. The authors used 
Zotero's bibliography software to assist in organizing the article. Furthermore, the included papers were reviewed one by one to determine the quality of the articles using a critical appraisal tool from Joanna Briggs Institute (JBI).

\section{RESULT AND DISCUSSION}

The article selection process following the PRISMA guidelines can be seen in figure 1 . These studies were conducted in several countries which were London with 530 pregnant women (Marcano-Belisario, et.al., 2017), China 3335 and 1304 (Gong, et.al., 2020; Mo, et.al., 2018), Sweden 42 (Forcell, et.al., 2017), Taiwan 135 (Tsai, et.al., 2018), New York 29 (Dennis-Tiwary, et.al., 2017), Canada 536 (Kingston, et.al., 2017), California 72 (Hantsoo, et.al., 2018), and South Africa 1144 (Tsai, et.al., 2014).

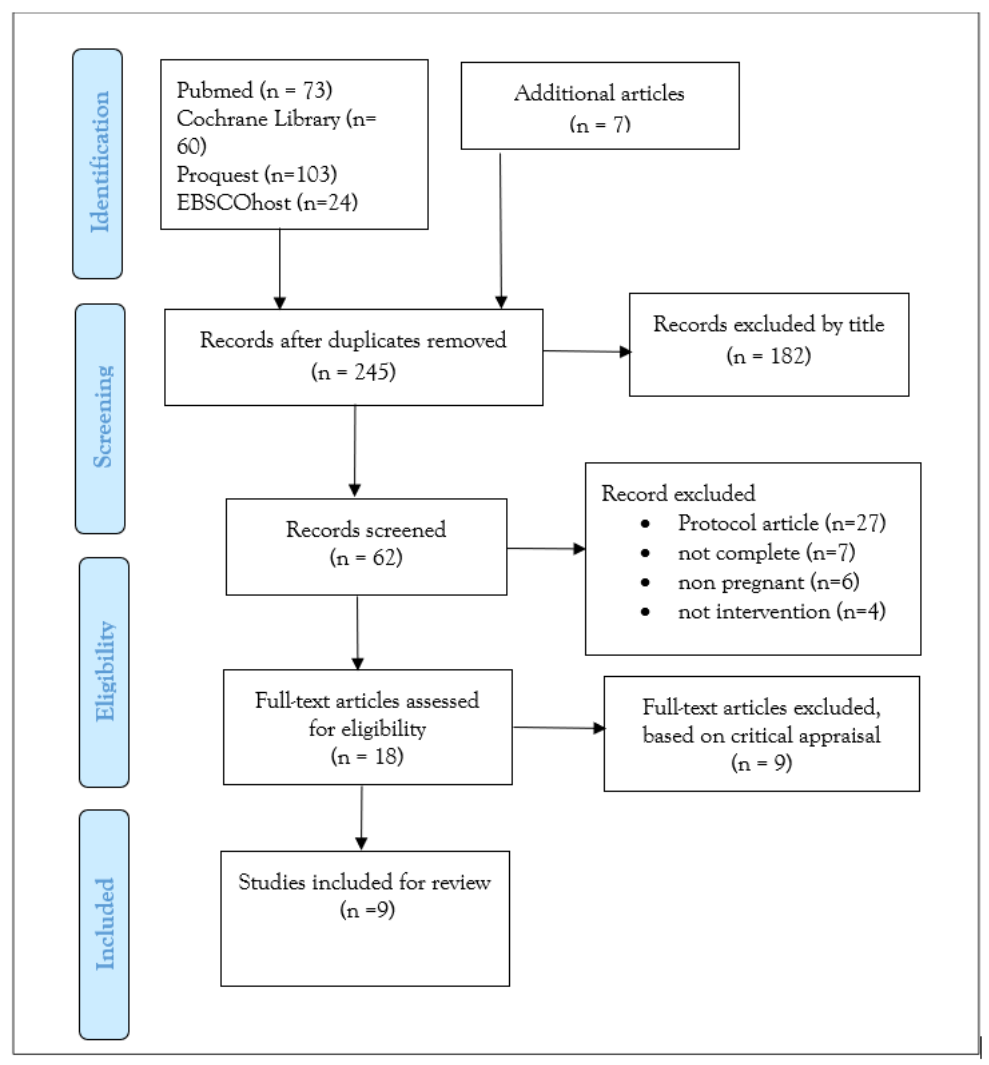

Figure 1. PRISMA Flow

Figure 1. PRISMA Flow

Table 2 shows characteristics of the study including design of the study and type of telehealth. There are five studies used research design with Randomized Controlled Trial (RCT), two studies were quasi-experimental studies and two cross-sectional studies. Moreover, the mode telehealth varied, the most using cellphones $n=5$ on study number 2,5,7-9 and computers $n=1$ on study number 1 , and a combination of $\mathrm{n}=3$ on study number $3,4,6$, while application-based $\mathrm{n}=4$ on study number $5,7-9$, and tablet computers $n=1$ on study number 1 , website $n=2$ on study number 4 and 6 , software $n=1$ on study number 1 , internet $n=1$ on study number 3 , SMS $n=1$ on study number 2. 


\section{Benefits of Telehealth ANC}

The research articles that have been reviewed showed some of the benefits of ANC with telehealth towards mental health among pregnant women:

\section{Screening}

Telehealth in pregnant women's health services can detect mental health problems for pregnant women. The Snap ${ }^{\circledR}$ survey software on a tablet computer, which contains questionnaires Whooley questions and the Edinburgh Postnatal Depression Scale (EPDS) which was a survey layout consists of two types: scrolling mode and paging mode. Futhermore, the result showed that there was no statistically significant relationship between the survey layout and the questionnaire used $\chi 2$ $(1, N=530=0.010247, p=0.919)$, that meaning the Whooley Question and EPDS can be used to detect maternal mental health. However, the other result showed that EPDS was significantly associated with the survey layout $\chi 2(2, \mathrm{~N}=530=9.6779, \mathrm{p}=0.008)$, compared to the Whooley Question (W = 35755, p = 0.700) (Marcano-Belisario et al., 2017). Further studies have also shown that EPDS-7 in mobile applications had a good sensitivity of 0.99 with a specificity of 0.85 to detect a possible problem in antenatal depression (Tsai et al., 2014). Apart from being able to detect a mental health problem, screening using telehealth can also provide the following benefits:

Minimizes time. The use of telehealth for the detection of mental health problems in pregnant women was less time-consuming than filling with paper-based (57.9\%, 54/302 vs. 40.9\%, 40/325) (Kingston et al., 2014). In addition, the use of time when filling out the questionnaire from e-screening, the average time required 285.5 seconds less time than filling out questionnaire from paper (Marcano-Belisario et al., 2017).

More Personal. Pregnant women more prefer to use e-screening compared to use paperbased screening when answer the mental health questions because it was more personal $(64.6 \%, 195 / 302$ vs. $31.7 \%, 103 / 325)$, but there was no statistically significant difference in the use of e-screening or paper-based-screening (Kingston et al., 2014).

Health services must always consider the benefits of using telehealth for consumers not only about costs, of course the clinical setting or hospitals must use strategies such as remuneration to improve health services to achieve it (Snoswell, et.al, 2020; Hidayah, 2020). Telehealth usage in clincal setting is a new branch of the future hospital and may be a major component in any hospital (Zhang \& Zhang, 2016). The result revealed some benefits of telehealth usage with ANC which preffered among pregnant women, which one is e-screening for detect mental health problem among pregnant women. However, the use of telehealth through e-screening did not differ in result from the use of paper-based-screening. This result is in line with other research that there was no difference in detecting anxiety and depression in adults with fibrosis cysts, whether using online screening or paper-based screening (Cronly et al., 2018). That means e-screening and paper-based-screening have the same function in detecting problems of mental health such as anxiety, depression, or stress. Escreening can be used as an alternative to assess pregnant women's mental health problem while queuing for ANC examinations (Marcano-Belisario et al., 2017). 


\section{Management of mental health problem}

Telehealth used together with ANC, can addressed mental health problem for pregnant women (Dennis-Tiwary et al., 2017; Forsell et al., 2017; Gong et al., 2020; Hantsoo et al., 2018; Tsai et al., 2018). Games via mobile phones like Attention Bias Modification Training (ABMT) showed stress and anxiety are reduced compared with the control group (Dennis-Tiwary et al., 2017). Moreover, the use of other applications such as Mood and Tracking Alerts (MTA) can also improve the mental health independently, where pregnant women can control their health because the application work system can detect mental health problem, so that health workers can easily contact them. Each pregnant woman who was risk or experience mental health problem showed that the total of phone calls was significantly correlate $\mathrm{p}<0.05$ (Hantsoo et al., 2018). Another study, Internet-based telehealth delivered cognitive behavior therapy (ICBT) use showed that the group that was given ICBT therapy experienced a significant decrease in depression levels $\mathrm{p}<0.001$ (Forsell et al., 2017). In addition, the web-based ANC intervention group reduced stress [P .001] and increase self-efficacy during the third trimester of pregnancy $(t=-3.17, \mathrm{P}=.001)$ (Tsai et al., 2018). Withal, the use of SMS showed EPDS for pregnant women were lower $(3.9 \pm 3.9$ vs $5.2 \pm 4.3, \mathrm{P}<.001)$, before the intervention participants were positive depression, after the intervention $76.6 \%$ of pregnant women $(232 / 303)$ were $57.5 \%$ negative (227/395), while group who did not receive SMS had higher EPDS scores in the third trimester $(\mathrm{AOR}=2.04,95 \% \mathrm{CI}=1.62-2.58)$ [48]. The use of ANC applications coincide with social media was a patron factor for pregnant women from depression (OR 0.33, 95\% CI 0.12-0.89) (Gong et al., 2020).

Telehealth can help monitor health, including mental health, in pregnant women. The use of tracking on mobile phone applications can help pregnant women and health workers track whether pregnant women have mental health problems (Hantsoo et al., 2018) Meanwhile, while using WebBased ANC, pregnant women could monitor their own health and blood pressure, fetus movement, uterus contraction and increase their capable to manage stress during pregnancy related to motherfetal health (Tsai et al., 2018).

The combination of telehealth usage and regular health care can encourage pregnant women to make ANC visits in timely manner, which is one of the important things for improving maternal health (Zhu, et.al, 2019). Telehealth with ANC can overcome mental health problems and monitor mental health problems. This study was in line with the previous study which reveals that telehealth based on stress management applications effectively improves mental health such as stress, depression, anxiety, and emotional and a positive index of welfare levels and increases self-efficacy (Hwang and Jo, 2019). Telehealth can be used as a one of management depression or anxiety during pregnancy, which interventions include psychoeducation and disease prevention (Hussain-Shamsy et al., 2020). 
Tabel 2. Summary of the included studies

\begin{tabular}{|c|c|c|c|c|c|}
\hline $\begin{array}{l}\text { Study } \\
\text { No. }\end{array}$ & $\begin{array}{l}\text { Author, } \\
\text { Year, } \\
\text { Country }\end{array}$ & Title & $\begin{array}{l}\text { Mode of } \\
\text { Telehealth }\end{array}$ & Research Design and Intervention & Key Conclusion \\
\hline 1 & $\begin{array}{l}\text { Marcano- } \\
\text { Belisario et } \\
\text { al., } 2017 \\
\text { London }\end{array}$ & $\begin{array}{l}\text { Implementation of } \\
\text { depression screening in } \\
\text { antenatal clinics through } \\
\text { tablet computers: } \\
\text { result of a feasibility study }\end{array}$ & $\begin{array}{l}\text { tablet } \\
\text { computers } \\
\text { [Apple® } \\
\text { iPads } \AA]\end{array}$ & $\begin{array}{l}\text { This study used an RCT design with block } \\
\text { randomization. The intervention was using } \\
\text { Snap survey software contains socio- } \\
\text { demographic data and depression detection } \\
\text { with Whooley questions and EPDS with a } \\
\text { paging layout or scrolling layout }\end{array}$ & $\begin{array}{l}\text { Tablet computers can be used to detect } \\
\text { symptoms of depression in pregnant women, } \\
\text { which can be applied when pregnant women } \\
\text { queue in the waiting room before performing an } \\
\text { ANC examination }\end{array}$ \\
\hline 2 & $\begin{array}{l}\text { Gong et al., } \\
2020 \text {, China }\end{array}$ & $\begin{array}{l}\text { Comprehensive intervention } \\
\text { during pregnancy based on } \\
\text { short message service to } \\
\text { prevent or alleviate } \\
\text { depression in pregnant } \\
\text { women: A quasi- } \\
\text { experimental study }\end{array}$ & $\begin{array}{l}\text { Comprehensiv } \\
\text { e intervention } \\
\text { based on SMS }\end{array}$ & $\begin{array}{l}\text { The research design was using the Quasi } \\
\text { Experiment. This study's intervention was SMS } \\
\text { that contains health education on how to } \\
\text { reduce the risk of depression during pregnancy } \\
\text { and a reminder of the schedule for conducting } \\
\text { ANC examinations. Intervention is given at } \\
\text { gestational age less than } 15 \text { weeks to 30-32 } \\
\text { weeks gestation }\end{array}$ & $\begin{array}{l}\text { Comprehensive SMS interventions can reduce } \\
\text { depression symptoms and lower favourable rates } \\
\text { of depression. The study also showed that the } \\
\text { control group had a higher risk of experiencing } \\
\text { depression in the third trimester than the } \\
\text { intervention group. Meantime, family income, } \\
\text { age, gestational age, and education affected } \\
\text { intervention effectiveness. }\end{array}$ \\
\hline 3 & $\begin{array}{l}\text { Forsell et al., } \\
2017 \\
\text { Sweden }\end{array}$ & $\begin{array}{l}\text { Internet-delivered cognitive } \\
\text { behavior therapy for } \\
\text { antenatal depression: A } \\
\text { randomized controlled trial }\end{array}$ & $\begin{array}{l}\text { Internet- } \\
\text { delivered } \\
\text { cognitive } \\
\text { behavior } \\
\text { therapy. }\end{array}$ & $\begin{array}{l}\text { The research design used RCT.The } \\
\text { intervention contained self-help instructions, } \\
\text { assessments, homework, and worksheets sent } \\
\text { via a secure online platform. The intervention } \\
\text { was given after ten weeks following the usual } \\
\text { ANC treatment, for ten weeks }\end{array}$ & $\begin{array}{l}\text { The result showed that ICBT with ANC was } \\
\text { significantly more effective to reduce antenatal } \\
\text { depression than the control group. }\end{array}$ \\
\hline 4 & $\begin{array}{l}\text { Tsai et al., } \\
2018, \\
\text { Taiwan }\end{array}$ & $\begin{array}{l}\text { Effects of a Web-Based } \\
\text { Antenatal Care System on } \\
\text { Maternal } \\
\text { Stress and Self-Efficacy } \\
\text { During Pregnancy: A Study } \\
\text { in Taiwan }\end{array}$ & $\begin{array}{l}\text { Web-based } \\
\text { ANC }\end{array}$ & $\begin{array}{l}\text { Quasi Experiment was the design. Web-based } \\
\text { ANC interventions include storing reports } \\
\text { related to ANC examinations that participants } \\
\text { can access to download examination reports. } \\
\text { Besides, Web-based ANC also provides } \\
\text { education, self-management journals, and birth } \\
\text { reports that can be saved. Pre-test at 16-24 } \\
\text { weeks gestation, } 36-38 \text { weeks post-test. }\end{array}$ & $\begin{array}{l}\text { The use of web-based ANC can reduce pregnant } \\
\text { women's stress in the third trimester and increase } \\
\text { self-efficacy during pregnancy compared to the } \\
\text { control group with ANC alone. }\end{array}$ \\
\hline 5 & $\begin{array}{l}\text { Dennis- } \\
\text { Tiwary et al., } \\
\text { 2017, New } \\
\text { York }\end{array}$ & $\begin{array}{l}\text { Salutary Effects of an } \\
\text { Attention Bias Modification } \\
\text { Mobile Application on } \\
\text { Biobehavioral Measures of } \\
\text { Stress and Anxiety during } \\
\text { Pregnancy }\end{array}$ & $\begin{array}{l}\text { Mobile ABMT } \\
\text { gamified }\end{array}$ & $\begin{array}{l}\text { The design in this research was RCT.The } \\
\text { intervention using ABMT game that was played } \\
\text { ten rounds for } 10 \text { minutes per day or four } \\
\text { days/week, the use of ABMT is carried out as } \\
\text { many as } 160 \text { rounds }\end{array}$ & $\begin{array}{l}\text { The use of gamified mobile ABMT with ANC } \\
\text { can effectively reduce the Biobehavioral index of } \\
\text { stress and anxiety in pregrant women. }\end{array}$ \\
\hline
\end{tabular}




\begin{tabular}{|c|c|c|c|c|c|}
\hline $\begin{array}{l}\text { Study } \\
\text { No. }\end{array}$ & $\begin{array}{l}\text { Author, } \\
\text { Year, } \\
\text { Country }\end{array}$ & Title & $\begin{array}{l}\text { Mode of } \\
\text { Telehealth }\end{array}$ & Research Design and Intervention & Key Conclusion \\
\hline 6 & $\begin{array}{l}\text { Kingston et } \\
\text { al., } 2017 \\
\text { Canada }\end{array}$ & $\begin{array}{l}\text { Pregnant Women's Views on } \\
\text { the Feasibility and } \\
\text { Acceptability of Web-Based } \\
\text { Mental Health E-Screening } \\
\text { Versus Paper-Based } \\
\text { Screening: A Randomized } \\
\text { Controlled Trial }\end{array}$ & $\begin{array}{l}\text { Web-Based } \\
\text { Mental Health } \\
\text { E-Screening }\end{array}$ & $\begin{array}{l}\text { The research design was RCT, the } \\
\text { intervention was using Web-Based Screening } \\
\text { tools which contain a psychosocial assessment } \\
\text { using a questionnaire the Antenatal } \\
\text { Psychosocial Health Assessment (ALPHA) and } \\
\text { EPDS }\end{array}$ & $\begin{array}{l}\text { e-screening has more benefits such as less time to } \\
\text { fill in data, more privacy so that every question } \\
\text { related to mental health is answered honestly, } \\
\text { and more pregnant women like the use of e- } \\
\text { screening compared to paper-based screening }\end{array}$ \\
\hline 7 & $\begin{array}{l}\text { Hantsoo et } \\
\text { al., 2018, } \\
\text { California }\end{array}$ & $\begin{array}{l}\text { A Mobile Application for } \\
\text { Monitoring and } \\
\text { Management of Depressed } \\
\text { Mood in a Vulnerable } \\
\text { Pregnant Population }\end{array}$ & $\begin{array}{l}\text { MTA } \\
\text { application }\end{array}$ & $\begin{array}{l}\text { The research design was RCT. MTA } \\
\text { intervention is given for eight weeks, the } \\
\text { application accesses the mood of pregnant } \\
\text { women, and if the mood of pregnant women is } \\
\text { bad, the application will send a warning to the } \\
\text { health care provider. }\end{array}$ & $\begin{array}{l}\text { The MTA group was significantly more able to } \\
\text { handle mental health problem for pregnant } \\
\text { women than the control group, the more } \\
\text { gestational age. Pregnant women were more able } \\
\text { to manage their health, pregnant women who } \\
\text { received warning calls on the MTA application } \\
\text { were significantly more likely to receive referrals } \\
\text { to a mental health specialist. Factor that affected } \\
\text { the MTA application was gestational age. }\end{array}$ \\
\hline 8 & $\begin{array}{l}\text { Tsai et al., } \\
\text { 2014, South } \\
\text { Afrika }\end{array}$ & $\begin{array}{l}\text { Antenatal depression case- } \\
\text { finding by community health } \\
\text { workers } \\
\text { in South Africa: feasibility of } \\
\text { a mobile phone application }\end{array}$ & $\begin{array}{l}\text { Mobile phone } \\
\text { application }\end{array}$ & $\begin{array}{l}\text { Cross-sectional was the research design in this } \\
\text { study. Meanwhile, the intervention used a } \\
\text { mobile application software containing the } \\
\text { Xhosa version of the EPDS questionnaire using } \\
\text { a short and ultra-short screening instrument. }\end{array}$ & $\begin{array}{l}\text { Mobile phone application contains short, and } \\
\text { ultra-short EPDS detection can detect antenatal } \\
\text { depression. The telehealth intervention program } \\
\text { with ANC is essential in health services by } \\
\text { working with related human resources to } \\
\text { improve pregnant women's mental health. }\end{array}$ \\
\hline 9 & $\begin{array}{l}\text { Mo et al., } \\
\text { 2018, China }\end{array}$ & $\begin{array}{l}\text { The Association Between the } \\
\text { Use of Antenatal Care } \\
\text { Smartphone Apps in } \\
\text { Pregnant Women and } \\
\text { Antenatal Depression: Cross- } \\
\text { Sectional Study }\end{array}$ & $\begin{array}{l}\text { Antenatal care } \\
\text { application } \\
\text { (acAPPs) on } \\
\text { smartphone }\end{array}$ & $\begin{array}{l}\text { The research design was Cross-sectional. The } \\
\text { intervention was using acAPPs to provide ANC } \\
\text { health services and information for pregnant } \\
\text { women and planning to become pregnant }\end{array}$ & $\begin{array}{l}\text { The use of acAPPs with social media may protect } \\
\text { against antenatal depression. The result also } \\
\text { showed that the level of depression in pregnant } \\
\text { women was detected to increase when accessing } \\
\text { related applications. } \\
\text { Disease-screening. Several factors such as family } \\
\text { income, age, and education influenced the } \\
\text { application use. }\end{array}$ \\
\hline
\end{tabular}




\section{Satisfaction}

Pregnant women who use Internet-based telehealth delivered cognitive behavior therapy (ICBT) had a good level of satisfaction with a satisfaction level score of 23.8 (Forsell et al., 2017). The use of Web-Based ANC showed a higher satisfaction level (88.13 vs. 85.37, P = .03) (Tsai et al., 2018). A lot of pregnant women were more likely prefer to use e-screening on emotional health compared to a paper-based screening $(57.9 \%$ vs $37.2 \%)$ and prefer to use e-screening (46,0\%, vs. 29.2\%) (Kingston et al., 2014). The ANC applications were very high usage among pregnant women $(930 / 1304,71.40 \%)$, with a frequency of using the application average 1-2 times per day [457/930, 49.4\%] (Mo et al., 2018).

The role of the level of satisfaction in using telehealth, of course, must be considered to determine whether telehealth is feasible to use. According to the other study that the level of satisfaction of telehealth was high (Butler Tobah et al., 2019). People living in rural and remote areas were generally satisfied with telehealth because it can increase access to health care and avoid discomfort during travel (Orlando et al., 2019). Meantime, the use of telehealth with ANC allowed pregnant women to find the knowledge of maternity care according to their own time, can be used anywhere such as when working, on transportation, and when with family, unexpensive, easier, improved communication with health providers, does not need to use transportation and was more personal (Mo et al., 2018; Kruse et al., 2017; Kingston et al., 2014).

\section{Factors affecting telehealth use}

Several factors influenced mental health-related telehealth use. There can be seen in Study No.2,7,9 which are listed on table 2:

\section{Family Income}

Income was significantly different between the use of the ANC application and those who did not use the ANC application $(\mathrm{P}=.001)$ with the result of income that uses a lot of applications around 5000-10000 yuan with 674 participants (51.3\%) (Mo et al., 2018). The findings from this study were also consistent with the other study that income had a significant relationship $(\mathrm{P}=.048)$, where pregnant women who receive comprehensive intervention via SMS with the most income ranges were $3001-5000$ yuan 575 participants (39.5\%) (Gong et al., 2020). In contrast to the several studies showed that income was not statistically significant relationship $(\mathrm{P}=.81)$ and $(\mathrm{P}=.805)$ (Kingston et al., 2014; (Tsai et al., 2018).

The family income of pregnant women who use telehealth was around 5000 yuan, which indicates that their income is not too much. This means that telehealth was widely used for lowincome people because the costs are affordable. This statement is supported by several studies that telehealth was less cost-effective than routine care (Bagayoko et al., 2014; Nord et al., 2019; Kao and Liebovitz, 2017; Marcolino et al., 2018). Generally, usual ANC requires more costs for health services, transportation or accommodation, but through technology-based ANC telehealth, pregnant women do not need to pay more.

Age

The research revealed that the women of age were significant associated with the use of the ANC application $(\mathrm{P}=.02)$ with an average age in the range of $25-29$ years as many as 500 participants (54.8\%) (Mo et al., 2018). Other research also explained age of women had a significant correlation 
with the use of SMS $(\mathrm{P}=0.050)$ with the mean of pregnant women age $28.7( \pm 4.3)$ years (Gong et al., 2020). Contrary to the results of those studies, in Taiwan and Canada the study result showed age did not have a significant relationship ( $\mathrm{P}=.51 ; \mathrm{P}=.653$ ) (Kingston et al., 2014; Tsai et al., 2018).

The average pregnant women who used telehealth with ANC ranged from 25 to 29 . The study is like other research which explains that most pregnant women who seek ANC health services are at the age of 25-30 years and over 30 years of age (Zhao et al., 2012). The previous study also showed pregnant women were using ANC over 25-34 years (Tran et al., 2012). That was possible because that age category is in the productive age range for having a child.

\section{Gestational Age}

The result showed that gestational age was also influence on telehealth use. Study showed gestational age had a significant relationship ( $\mathrm{P}=<$. 001) (Gong et al., 2020). Another study also explained that gestational age affected telehealth use based on the MTA application $(\mathrm{P}=.02)$ (Hantsoo et al., 2018). The results of those studies were inversely proportional to one of study, there was no significant correlation between gestational age and the use of web-based mental health screening-based telehealth $(\mathrm{P}=.22)$ (Kingston et al., 2014).

The mental health problems were mostly in the third trimester of pregnancy. This study was in line with others study which was mental health problems such as stress, anxiety, and depression were often felt in the third trimester of pregnancy because they were increasingly the proximity of the delivery process (Dennis et al., 2017; Effati-Daryani et al., 2018; Silva et al., 2017). The approaching labor often causes anxiety in the third trimester, and pregnant women are more anxious about their health and their babies' health (Pesonen et al., 2016).

\section{Education}

Several studies showed that the level of education of pregnant women was a number factor that affected the use of telehealth with ANC. The study showed a significant value $(\mathrm{P}<.00)$ with the most participants were students 729 students (60.3\%) (Mo et al., 2018). The results of the similar study also showed $(\mathrm{P}<.001)$ with the most participants were students or education above 1052 participants (71.1\%) (Gong et al., 2020). The different study showed that education had no relationship $(P=.29)$ (Kingston et al., 2014).

The level of education of pregnant women affected the effectiveness of using telehealth. This study is in line with that education has a relationship with ANC service participation (Tk et al., 2012; Tarekegn et al., 2014; Tekelab et al., 2019). Pregnant women with low education have inadequate ANC health services (Tiruaynet and Muchie, 2019; Tran et al., 2012). Furthermore, educated women tend to be more aware of health, understand the use of healthcare services, and use information more effeciently than women who are not educated (Aziz Ali et al., 2020). Pregnant women who have a higher education have more knowledge obtained through various sources of information, including telehealth used.

\section{CONCLUSION}

This review literature identifies the main benefits of implementing telehealth with ANC for pregnant women's mental health, such as early detection of mental health problems and the management of mental health problems, and the public well accepts the use of telehealth with good satisfaction. Income, education, age of pregnant women, and gestational age can influence telehealth 
use's effectiveness. The existence of distance restrictions during the COVID-19 pandemic hampered ANC services. This review can certainly be used as information for healthcare providers to maintain access to the ANC services in the context of the COVID-19 pandemic through telehealth.

\section{ACKNOWLEDGMENT}

Acknowledge the Ministry of Research and Technology, the National Research and Innovation Agency as the provider of research funds

\section{REFERENCES}

Abosse Z, Woldie M, Ololo S. Factors Influencing Antenatal Care Service Utilization in Hadiya Zone. Ethiop J Health Sci. 2010 Jul;20[2]:75-82.

Agus Y, Horiuchi S. Factors influencing the use of antenatal care in rural West Sumatra, Indonesia. BMC Pregnancy Childbirth. 2012 Feb 21;12[1]:9.

Aziz Ali S, Aziz Ali S, Feroz A, Saleem S, Fatmai Z, Kadir MM. Factors affecting the utilization of antenatal care among married women of reproductive age in the rural Thatta, Pakistan: findings from a community-based case-control study. BMC Pregnancy Childbirth. 2020 Jun 10;20[1]:355.

Bagayoko CO, Traoré D, Thevoz L, Diabaté S, Pecoul D, Niang M, et al. Medical and economic benefits of telehealth in low- and middle-income countries: result of a study in four district hospitals in Mali. BMC Health Serv Res. 2014 May 12;14[1]:S9.

Benski AC, Schmidt NC, Viviano M, Stancanelli G, Soaroby A, Reich MR. Improving the Quality of Antenatal Care Using Mobile Health in Madagascar: Five-Year Cross-Sectional Study. JMIR MHealth UHealth. 2020 Jul 8;8[7]:e18543.

Biaggi A, Conroy S, Pawlby S, Pariante CM. Identifying the women at risk of antenatal anxiety and depression: A systematic review. J Affect Disord. 2016 Feb 1;191:62-77.

Butler Tobah YS, LeBlanc A, Branda ME, Inselman JW, Morris MA, Ridgeway JL, et al. Randomized comparison of a reduced-visit prenatal care model enhanced with remote monitoring. Am J Obstet Gynecol. 2019 Dec;221[6]:638.e1-638.e8.

Chen M, Liu X, Zhang J, Sun G, Gao Y, Shi Y, et al. Characteristics of online medical care consultation for pregnant women during the COVID-19 outbreak: cross-sectional study. BMJ Open. 2020 Nov;10[11]:e043461.

Cronly J, Duff AJ, Riekert KA, Perry IJ, Fitzgerald AP, Horgan A, et al. Online versus paper-based screening for depression and anxiety in adults with cystic fibrosis in Ireland: a cross-sectional exploratory study. BMJ Open. 2018 Jan 1;8[1]:e019305.

Dennis-Tiwary TA, Denefrio S, Gelber S. Salutary effects of an attention bias modification mobile application on biobehavioral measures of stress and anxiety during pregnancy. Biol Psychol. 2017 Jul;127:148-56.

Duko B, Ayano G, Bedaso A. Depression among pregnant women and associated factors in Hawassa city, Ethiopia: an institution-based cross-sectional study. Reprod Health. 2019 Feb $28 ; 16[1]: 25$. 
Effati-Daryani F, Zarei S, Mohammadi A, Hemmati E, Ghasemi Yngyknd S, Mirghafourvand M. Depression, stress, anxiety and their predictors in Iranian pregnant women during the outbreak of COVID-19. BMC Psychol. 2020 Dec;8[1]:99.

Fawcett EJ, Fairbrother N, Cox ML, White IR, Fawcett JM. The Prevalence of Anxiety Disorders During Pregnancy and the Postpartum Period: A Multivariate Bayesian Meta-Analysis. J Clin Psychiatry. 2019 Jul 23;80[4]:0-0.

Forsell E, Bendix M, Holländare F, Szymanska von Schultz B, Nasiell J, Blomdahl-Wetterholm M, et al. Internet delivered cognitive behavior therapy for antenatal depression: A randomised controlled trial. J Affect Disord. 2017 Oct 15;221:56-64.

Franke K, Van den Bergh BRH, de Rooij SR, Kroegel N, Nathanielsz PW, Rakers F, et al. Effects of maternal stress and nutrient restriction during gestation on offspring neuroanatomy in humans. Neurosci Biobehav Rev. 2020 Oct 1;117:5-25.

Gong M, Zhang S, Xi C, Luo M, Wang T, Wang Y, et al. Comprehensive intervention during pregnancy based on short message service to prevent or alleviate depression in pregnant women: A quasi-experimental study. Early Interv Psychiatry [Internet]. 2020 Mar 30 [cited 2020 Dec 22]; Available from: http://doi.wiley.com/10.1111/eip.12953

Hantsoo L, Criniti S, Khan A, Moseley M, Kincler N, Faherty LJ, et al. A Mobile Application for Monitoring and Management of Depressed Mood in a Vulnerable Pregnant Population. Psychiatr Serv Wash DC. 2018 Jan 1;69[1]:104-7.

Hartman S, Eilertsen EM, Ystrom E, Belsky J, Gjerde LC. Does prenatal stress amplify effects of postnatal maternal depressive and anxiety symptoms on child problem behavior? Dev Psychol. 2020 Jan;56[1]:128-37.

Hidayah, N., Dewi, A., \& Listiowati, E. (2020). Remuneration as a strategy to improve service quality, cost-effectiveness, and organizational performance of private hospitals. Enfermería Clínica, 30, 179-182. https://doi.org/10.1016/j.enfcli.2020.06.077

Howard LM, Khalifeh H. Perinatal mental health: a review of progress and challenges. World Psychiatry. 2020;19[3]:313-27.

Hussain-Shamsy N, Shah A, Vigod SN, Zaheer J, Seto E. Mobile Health for Perinatal Depression and Anxiety: Scoping Review. J Med Internet Res. 2020 Apr 13;22[4]:e17011.

Hwang WJ, Jo HH. Evaluation of the Effectiveness of Mobile App-Based Stress-Management Program: A Randomized Controlled Trial. Int J Environ Res Public Health [Internet]. 2019 Nov [cited 2021 Jan 10];16[21]. Available from: https://www.ncbi.nlm.nih.gov/pmc/articles/PMC6862035/

Johnson AR, George M, Goud BR, Sulekha T. Screening for Mental Health Disorders among Pregnant Women Availing Antenatal Care at a Government Maternity Hospital in Bengaluru City. Indian J Psychol Med. 2018;40[4]:343-8.

Kao C-K, Liebovitz DM. Consumer Mobile Health Apps: Current State, Barriers, and Future Directions. PM R. 2017 May;9[5S]:S106-15. 
Khatri GK, Tran TD, Fisher J. Prevalence and determinants of symptoms of antenatal common mental disorders among women who had recently experienced an earthquake: a systematic review. BMC Psychiatry. 2019 Jan 28;19[1]:47.

Kingston D, Austin M-P, Veldhuyzen van Zanten S, Harvalik P, Giallo R, McDonald SD, et al. Pregnant Women's Views on the Feasibility and Acceptability of Web-Based Mental Health E-Screening Versus Paper-Based Screening: A Randomized Controlled Trial. J Med Internet Res. 2017 Apr 7;19[4]:e88.

Konlan KD, Saah JA, Amoah RM, Doat AR, Mohammed I, Abdulai JA, et al. Factors influencing the utilization of Focused antenatal care services during pregnancy, a study among postnatal women in a tertiary healthcare facility, Ghana. Nurs Open. 2020;7[6]:1822-32.

Korja R, Nolvi S, Grant KA, McMahon C. The Relations Between Maternal Prenatal Anxiety or Stress and Child's Early Negative Reactivity or Self-Regulation: A Systematic Review. Child Psychiatry Hum Dev. 2017 Dec;48[6]:851-69.

Krenitsky NM, Spiegelman J, Sutton D, Syeda S, Moroz L. Primed for a pandemic: Implementation of telehealth outpatient monitoring for women with mild COVID-19. Semin Perinatol. 2020 Jul 21;151285.

Kruse CS, Krowski N, Rodriguez B, Tran L, Vela J, Brooks M. Telehealth and patient satisfaction: a systematic review and narrative analysis. BMJ Open. 2017 Aug;7[8]:e016242.

Lanssens D, Vandenberk T, Thijs IM, Grieten L, Gyselaers W. Effectiveness of Telemonitoring in Obstetrics: Scoping Review. J Med Internet Res. 2017 27;19[9]:e327.

Lautarescu A, Craig MC, Glover V. Chapter Two - Prenatal stress: Effects on fetal and child brain development. In: Clow A, Smyth N, editors. International Review of Neurobiology [Internet]. Academic Press; 2020 [cited 2020 Dec 20]. p. 17-40. [Stress and Brain Health: Across the Life Course; vol. 150]. Available from: http://www.sciencedirect.com/science/article/pii/S0074774219301199

Lewis AJ, Austin E, Galbally M. Prenatal maternal mental health and fetal growth restriction: a systematic review. J Dev Orig Health Dis. 2016 Aug;7[4]:416-28.

Madigan S, Oatley H, Racine N, Fearon RMP, Schumacher L, Akbari E, et al. A Meta-Analysis of Maternal Prenatal Depression and Anxiety on Child Socioemotional Development. J Am Acad Child Adolesc Psychiatry. 2018 Sep;57[9]:645-657.e8.

Marcano-Belisario JS, Gupta AK, O’Donoghue J, Ramchandani P, Morrison C, Car J. Implementation of depression screening in antenatal clinics through tablet computers: result of a feasibility study. BMC Med Inform Decis Mak. 2017 May 10;17[1]:59.

Marcolino MS, Oliveira JAQ, D’Agostino M, Ribeiro AL, Alkmim MBM, Novillo-Ortiz D. The Impact of mHealth Interventions: Systematic Review of Systematic Reviews. JMIR MHealth UHealth. 2018 Jan 17;6[1]:e23.

Mizrak Sahin B, Kabakci EN. The experiences of pregnant women during the COVID-19 pandemic in Turkey: A qualitative study. Women Birth. 2020 Oct;S1871519220303401. 
Mo Y, Gong W, Wang J, Sheng X, Xu DR. The Association Between the Use of Antenatal Care Smartphone Apps in Pregnant Women and Antenatal Depression: Cross-Sectional Study. JMIR MHealth UHealth [Internet]. 2018 Nov 29 [cited 2021 Jan 7];6[11]. Available from:https://www.ncbi.nlm.nih.gov/pmc/articles/PMC6293246/

Mongan D, Lynch J, Hanna D, Shannon C, Hamilton S, Potter C, et al. Prevalence of self-reported mental disorders in pregnancy and associations with adverse neonatal outcomes: a population-based cross-sectional study. BMC Pregnancy Childbirth. 2019 Nov 8;19[1]:412.

Mossie TB, Sibhatu AK, Dargie A, Ayele AD. Prevalence of antenatal depressive symptoms and associated factors among pregnant women in Maichew, North Ethiopia: an institution based study. Ethiop J Health Sci. 2017 Feb 6;27[1]:59-66.

Nord G, Rising KL, Band RA, Carr BG, Hollander JE. On-demand synchronous audio video telemedicine visits are cost effective. Am J Emerg Med. 2019 May 1;37[5]:890-4.

Orlando JF, Beard M, Kumar S. Systematic review of patient and caregivers' satisfaction with telehealth videoconferencing as a mode of service delivery in managing patients' health. PLOS ONE. 2019 Agu;14[8]:e0221848.

Pesonen A-K, Lahti M, Kuusinen T, Tuovinen S, Villa P, Hämäläinen E, et al. Maternal Prenatal Positive Affect, Depressive and Anxiety Symptoms and Birth Outcomes: The PREDO Study. PLOS ONE. 2016 Feb 26;11[2]:e0150058.

Sheeba B, Nath A, Metgud CS, Krishna M, Venkatesh S, Vindhya J, et al. Prenatal Depression and Its Associated Risk Factors Among Pregnant Women in Bangalore: A Hospital Based Prevalence Study. Front Public Health [Internet]. 2019 [cited 2021 Jan 21];7. Available from: https://www.frontiersin.org/articles/10.3389/fpubh.2019.00108/full

Silva MM de J, Nogueira DA, Clapis MJ, Leite EPRC. Anxiety in pregnancy: prevalence and associated factors. Rev Esc Enferm U P. 2017 Aug 28;51:e03253.

Snoswell, C. L., Taylor, M. L., Comans, T. A., Smith, A. C., Gray, L. C., \& Caffery, L. J. (2020). Determining if Telehealth Can Reduce Health System Costs: Scoping Review. Journal of Medical Internet Research, 22(10). https://doi.org/10.2196/17298

Tarekegn SM, Lieberman LS, Giedraitis V. Determinants of maternal health service utilization in Ethiopia: analysis of the 2011 Ethiopian Demographic and Health Survey. BMC Pregnancy Childbirth. 2014 May 7;14:161.

Tekelab T, Chojenta C, Smith R, Loxton D. Factors affecting utilization of antenatal care in Ethiopia: A systematic review and meta-analysis. PloS One. 2019;14[4]:e0214848.

Terefe AN, Gelaw AB. Determinants of Antenatal Care Visit Utilization of Child-Bearing Mothers in Kaffa, Sheka, and Bench Maji Zones of SNNPR, Southwestern Ethiopia. Health Serv Res Manag Epidemiol. 2019 Jan 1;6:2333392819866620.

Tiruaynet K, Muchie KF. Determinants of utilization of antenatal care services in Benishangul Gumuz Region, Western Ethiopia: a study based on demographic and health survey. BMC Pregnancy Childbirth. 2019 Apr 3;19[1]:115. 
Tk T, K G, Hd N, H A, M P. Factors associated with antenatal care adequacy in rural and urban contexts-result from two health and demographic surveillance sites in Vietnam [Internet]. Vol. 12, BMC health services research. BMC Health Serv Res; 2012 [cited 2021 Jan 11]. Available from: https://pubmed.ncbi.nlm.nih.gov/22335834/

Tran TK, Gottvall K, Nguyen HD, Ascher H, Petzold M. Factors associated with antenatal care adequacy in rural and urban contexts-result from two health and demographic surveillance sites in Vietnam. BMC Health Serv Res. 2012 Feb 15;12:40.

Tsai AC, Tomlinson M, Dewing S, le Roux IM, Harwood JM, Chopra M, et al. Antenatal depression case finding by community health workers in South Africa: feasibility of a mobile phone application. Arch Womens Ment Health. 2014 Oct;17[5]:423-31.

Tsai Y-J, Hsu Y-Y, Hou T-W, Chang C-H. Effects of a Web-Based Antenatal Care System on Maternal Stress and Self-Efficacy During Pregnancy: A Study in Taiwan. J Midwifery Womens Health. 2018;63[2]:205-13.

Tuckson RV, Edmunds M, Hodgkins ML. Telehealth. N Engl J Med. 2017 Oct 19;377[16]:158592.

Tunçalp Ö., Pena-Rosas JP, Lawrie T, Bucagu M, Oladapo OT, Portela A, et al. WHO recommendations on antenatal care for a positive pregnancy experience-going beyond survival. BJOG Int J Obstet Gynaecol. 2017;124[6]:860-2.

Van den Beld AW, Kaufman J-M, Zillikens MC, Lamberts SW, Egan JM, van der Lely AJ. The physiology of endocrine systems with ageing. Lancet Diabetes Endocrinol. 2018 Aug;6[8]:647-58.

Wallwiener S, Goetz M, Lanfer A, Gillessen A, Suling M, Feisst M, et al. Epidemiology of mental disorders during pregnancy and link to birth outcome: a large-scale retrospective observational database study including 38,000 pregnancies. Arch Gynecol Obstet. 2019 Mar $1 ; 299[3]: 755-63$.

Watterson JL, Walsh J, Madeka I. Using mHealth to Improve Usage of Antenatal Care, Postnatal Care, and Immunization: A Systematic Review of the Literature [Internet]. Vol. 2015, BioMed Research International. Hindawi; 2015 [cited 2021 Jan 25]. p. e153402. Available from: https://www.hindawi.com/journals/bmri/2015/153402/

Wesselhoeft R, Davidsen K, Sibbersen C, Kyhl H, Talati A, Andersen MS, et al. Maternal prenatal stress and postnatal depressive symptoms: discrepancy between mother and teacher reports of toddler psychological problems. Soc Psychiatry Psychiatr Epidemiol. 2020 Sep 29;

Woldetsadik AM, Ayele AN, Roba AE, Haile GF, Mubashir K. Prevalence of common mental disorder and associated factors among pregnant women in South-East Ethiopia, 2017: a community based cross-sectional study. Reprod Health. 2019 Nov 28;16[1]:173.

WHO | Prevalence and determinants of common perinatal mental disorders in women in low-and lower-middle-income countries: a systematic review [Internet]. WHO. World Health Organization; [cited 2021 Jan 21]. Available from: https://www.who.int/bulletin/volumes/90/2/11-091850/en/ 
World Health Organization. WHO Recommendations on Antenatal Care for a Positive Pregnancy Experience. World Health Organization; 2016. 152 p.

Wu J-R, Cummings DM, Li Q, Hinderliter A, Bosworth HB, Tillman J, et al. The effect of a practicebased multicomponent intervention that includes health coaching on medication adherence and blood pressure control in rural primary care. J Clin Hypertens Greenwich Conn. 2018;20[4]:757-64.

Yu Y, Zhu X, Xu H, Hu Z, Zhou W, Zheng B, et al. Prevalence of depression symptoms and its influencing factors among pregnant women in late pregnancy in urban areas of Hengyang City, Hunan Province, China: a cross-sectional study. BMJ Open. 2020 Sep 1;10[9]:e038511.

Zhang, X.-Y., \& Zhang, P. (2016). Telemedicine in clinical setting. Experimental and Therapeutic Medicine, 12(4), 2405-2407. https://doi.org/10.3892/etm.2016.3656

Zhao Q, Huang ZJ, Yang S, Pan J, Smith B, Xu B. The utilization of antenatal care among rural-tourban migrant women in Shanghai:a hospital-based cross-sectional study. BMC Public Health. 2012 Nov 21;12[1]:1012.

Zhu, X.-H., Tao, J., Jiang, L.-Y., \& Zhang, Z.-F. (2019, May 6). Role of Usual Healthcare Combined with Telemedicine in the Management of High-Risk Pregnancy in Hangzhou, China [Research Article]. Journal of Healthcare Engineering; Hindawi. https://doi.org/10.1155/2019/3815857

Zork NM, Aubey J, Yates H. Conversion and optimization of telehealth in obstetric care during the COVID-19 pandemic. Semin Perinatol. 2020 Oct;44[6]:151300. 